\title{
TTR
}

Traduction, terminologie, re?daction

\section{Does Hortense Have a Hoo-Hoo? Gender, Consensus, and the Translation of Gisèle Pineau's L'espérance-macadam}

\section{Aletha Stahl}

Volume 13, numéro 2, 2e semestre 2000

Les Antilles en traduction

The Caribbean in Translation

URI : https://id.erudit.org/iderudit/037414ar

DOI : https://doi.org/10.7202/037414ar

Aller au sommaire du numéro

Éditeur(s)

Association canadienne de traductologie

ISSN

0835-8443 (imprimé)

1708-2188 (numérique)

Découvrir la revue

Citer cet article

Stahl, A. (2000). Does Hortense Have a Hoo-Hoo? Gender, Consensus, and the Translation of Gisèle Pineau's L'espérance-macadam. TTR, 13(2), 127-148. https://doi.org/10.7202/037414ar

\section{Résumé de l'article}

Est-ce que Hortense a un « Hoo-Hoo »? Traduction au féminin de L'espérance-macadam de Gisèle Pineau - Dans cet article, une expérience de la traduction collective du roman L'espérance-macadam de Gisèle Pineau (Guadeloupe) sert de point de départ à l'étude de la traduction d'oeuvres des Antilles françaises pour un public anglophone. Les efforts de traduction effectués jusqu'ici ont tendance à susciter un débat sur les difficultés de la représentation du continuum linguistique aux Antilles francophones et créolophones. Pour notre part, nous proposons ici que certains choix lexicaux de la part de l'écrivaine constituent une représentation importante de la femme antillaise et qu'une conscience du rôle du genre dans le langage est pertinente à toute traduction en anglais. D'ailleurs, si le désir de la part de ceux et celles qui traduisent n'est pas toujours innocent, cette conscience du genre et de la spécificité locale peut contribuer au processus de consensus qui fait partie de l'édition, et c'est ainsi qu'elle mérite un rôle au sein des débats concernant les Antilles françaises en général.
Tous droits réservés (C) TTR: traduction, terminologie, rédaction — Les auteurs, 2000
Ce document est protégé par la loi sur le droit d'auteur. L'utilisation des services d'Érudit (y compris la reproduction) est assujettie à sa politique d'utilisation que vous pouvez consulter en ligne.

https://apropos.erudit.org/fr/usagers/politique-dutilisation/ 


\section{Does Hortense Have a Hoo-Hoo? Gender, Consensus, and the Translation of Gisèle Pineau's L'espérance-macadam}

\section{Aletha Stahl}

The difficulty of translating from a language that doesn't yet exist is considerable, but there's no need to exaggerate it. Ursula K. Le Guin

For those who miss the echoes of Dr. Seuss' children's book Horton Hears a Who in my title, please know that this intertextual reference is not necessary for following my inquiry into translation and gender in Guadeloupean writer Gisèle Pineau's 1995 novel, L'espérancemacadam. The small group of women students with whom I am translating the text into English simply could not resist the comparison. The masculine Horton, an elephant in the children's book, becomes the feminine Hortense, a character in the novel. "Hoo-hoo" is, at this point, one option for translating the Creole term coucoune - female genitals - and is central to the reading of the novel we perform through the act of translation. The very lack of a widely current term in English with similar connotations, not to mention that the term was borrowed from Creole for use in a primarily French text, exemplifies frictions involved in translating this woman-centered novel. By addressing some of these frictions, I hope to ignite further debate on the ways in which the French Caribbean works itself into the geopolitical space of Englishdominated Canada and the United States. 


\section{I. "Translating the French Caribbean": A Pedagogical Experiment}

I will begin with a summary of our translation process so as to highlight issues in a practice that concerns those of us who, as professors, readers, and translators, are at times laden with a poststructural consciousness of the omnipresence of ideology and relations of power - an angst that, at least for me, arises from some of the privileges of my position (white, middle-class, in a tenure-track job) as I teach and practice translation with a focus on the French Caribbean.

In 1998, the institution in which I am employed, Earlham College, awarded me a grant for a collaborative faculty/student research project I called "Translating the French Caribbean: Theory and Practice". The project consisted of working with seven undergraduate students to read and discuss translation theories while producing an English version of L'espérance-macadam. This novel focuses on an elderly woman, Éliette, as she moves beyond self-protective passivity to face the incest she experienced as a child and to take action against the violence of her socially - and economically - deprived neighborhood in Guadeloupe. The setting of much of the novel corresponds with the arrival of Hurricane Hugo in 1988. As has become current in recent fiction from the French Caribbean, the novel not only includes direct discourse in Creole but its French is also heavily inflected by this language and by regional linguistic practices. This is not to say that it is a mere reflection of French Caribbean language, but that the language plays off the spectrum of language available to speakers of both French and a Creole developed largely from a French lexical base.

After completing readings in translation theories of postcolonialism and hegemony and creating a bibliography designed to fill in gaps we identified in the group's preparation, the students and I divided the first chapter and began translating in pairs who in turn solicited feedback from the entire group. When several students asked to continue the project in subsequent semesters, we translated on our own but brought all our work to the group for critique. Group time in both instances entailed arguing over translation details and working to develop consistency among the various sections.

To make decisions, we used Quaker-style consensus - a crucial aspect of this experiment since one of my questions was how to 
go about collective translation. A Quaker model of consensus decision making can be described as a network of ideas originating from but not representing various individuals. While it may seem naïve to allude to individuals, in many ways, this process takes into account notions of subjectivity insofar as it allows for contradictory ideas to emerge from the same source. The objective is for everyone to listen carefully while weaving together all ideas until there is a sense that an agreement can be reached. Like a node on a network, the decision agreed upon becomes simultaneously the product of all ideas and the point of reference for subsequent decisions. To make the process as equitable as possible, group members present ideas and express differences with care (all the more so when they are in positions of power, as was my case), at times accepting the will of the group so as not to lead to an impasse. However, if anyone holds a strong opinion, it is important that it be expressed and considered seriously to ensure that a critical perspective is not overlooked and if possible, to integrate the diverging point of view into the final decision. For our group, decisions submitted to this process of consensus ranged from lexical choice to matters of our own organization and translation methods.

Working with eight people to achieve the unity of consensus (and I underscore unity, not unanimity, which implies another kind of accord) takes time, patience, and a commitment to the process itself. At times the going was slow for us. For example, the second sentence of the novel, Rien que les immondices, was brought up for debate at least three times. "Debris," my initial preference given the novel's posthurricane opening, might relay the idea of the destruction of something that had appeared to be more intact, i.e., Éliette's immutability and by extension, that of Guadeloupe. I saw in "debris" a lack of judgment that is less certain in the other alternatives we debated - "trash" and "filth" - which for me initially implicated all of Guadeloupe's inhabitants and suggested a more negative metonymy for the island. When in our final editorial session for this chapter we reached consensus on making the second sentence "Nothing but filth," students marked the occasion and our collaboration by having this quote printed on t-shirts.

In enrolling in the project, students dreamed of seeing their names figure under that of Gisèle Pineau on the colorful cover of a paperback and perhaps even of earning a few US dollars from a publisher. However, as we read about and discussed postcolonial issues and the status of translation on the North American continent, their objectives shifted. At the end of the initial semester, which included 
three days of collaboration with the author on our campus, I asked students to take a stand on the future of our work. Half the group took the position that we should not be the ones to try to publish the translation in English. They argued either that using consensus with such a large group was too difficult to advance in the work or that we did not have the skills and cultural knowledge they felt were required. All students nevertheless agreed that L'espérance-macadam ought to appear in English, largely due to its content. During Pineau's visit, she told moving stories about the ways the novel had spoken to survivors of incest who in turn thanked her for writing about the experience. These stories had already been corroborated during the semester when one student took me aside to say that she might not be able to continue working with the group if her classmates kept making off-the-cuff comments about the "grossness" of incest. It is significant that despite - or perhaps because of - her history, which she has since shared with me, she persevered and ultimately stood with the other half of the group in calling for us to take up the entire translation project ourselves. As a result, several students continued working with me both on the translation and on independent studies of gender and translation and identity theories of the French Caribbean.

\section{A Word on Authors (We Thought Were Dead) and Translators}

Beyond reasons of theme, students took the position that the novel ought to appear in English for another key reason that is, I believe, germane to questions of consensus and of translation in general. Namely, and despite my mini lectures on twentieth-century literary criticism and the fallacy of authorial intention, students argued that our efforts could fulfill the wishes of the author, who expressed enthusiasm for our work and articulated a desire to extend public dialogue by publishing in English. My point is that for these students, the author was indeed living, and they situated the significance and the signification of the novel in her stated desires, in what she could explain to us, and in what might be called "the text itself". Suggestions that we might at times "improve" on the original, that we should question certain representations in the novel, and that we should not wholeheartedly adopt the author's explanation of a given passage struck them as almost sacrilegious.

The students' difficulty in distancing themselves from a living author is not necessarily something that I want to discourage, since I also hold that consultation should take place as widely as possible and 
that living authors' wishes should play into the "consensus" process that moves any document through translation and into publication in another language. Here, too often this "consensus" becomes a matter of deferral on the part of authors and translators to institutions determining publishing, marketing, and even copyright practices rather than a means of challenging certain power differentials. Nevertheless, and as I hoped the students would see, it is in demystifying the paternity attributed to "author" (and to ourselves as "translators") that a more egalitarian form of consensus can ultimately take place. I build this notion on Michel Foucault's proposal that "author function" rather than "author" be used to suggest the system organizing discourse. This "author function" does not concern all discourses in the same manner and can be defined by a series of complex operations rather than the spontaneous attribution of a discourse to its producer. Above all, it does not allude to a real individual because, as with my description of consensus decision-making at its best, it can elicit multiple subject positions (p. 153). Foucault implicates the terms "work" and "writing" in his critique since they insinuate the authority of the producer of the discourse and thus participate in the myth of the author. I add the word "text" to this list given that, as Tony Bennett argues, in calling on that which is found in the "text itself," we create a hierarchy of readings according to their conformity to that which an analysis of the "text itself" confirms to be the most correct or most authoritative (p. 10). More appropriate, Bennett suggests, is the study of the text and its public as "activated" culturally. This approach allows for recognizing the material, social, and ideological ties that inevitably structure both "text" and public (p. 12).

In adopting these ideas, it is important not to erase the question of the conditions of production of a discourse often linked with the more simplistic notion of the author. Feminist and postcolonial critics underscore the relations of power that permit some discourses to be produced by certain people and to circulate in certain venues while others never reach specific audiences or are never produced. Foucault ultimately predicts a return to the circulation of discourses as they were in the distant past, that is, a time when the author function will disappear to be replaced by another system of constraints where the questions asked will no longer concern the life and authority of the author but rather the modes of existence of the discourse: its use, its circulation, and those who appropriate it; and the resulting questions of subjectivity. These questions, I suggest, are indeed paramount to translation. But the "modes of existence" are 
inflected precisely by the "life" of the author, which all too often determines his or her authority. In translating L'espérance-macadam, we straddle the divide between a discourse's "modes of existence" and the possibility of dialoguing face to face with an author whose life and authority, as mediated by publishers and other institutions, is hardly defunct; in short, we are still far from the death of the author function as Foucault imagines it. For this reason, it seems only appropriate to include consultation with Pineau in our efforts.

Since translation is above all a way of reading, these issues also apply to our work in another way. One of several reasons I selected L'espérance-macadam for our project is the fact that its author is a woman of color, and furthermore, a creolophone and francophone woman of color from both France and Guadeloupe, the latter of which often finds itself in opposition to constraints arising from its status within the nation-state of the former. I don't presume that these reasons are good enough for selecting the novel, and I certainly don't want to essentialize the author or burden her with a particular agenda for writing. However - and here I return to the angst of the post-structural translator - I am cognizant of how these identity "categories" have been historically determined and used to manage and control groups of people, and that inevitably such determinations shape the circulation of this particular novel cum discourse.

Here, it is noteworthy that fiction by women writers of color today enjoys a certain popularity that did not exist in the past. Hence Toni Morrison, Alice Walker, and even Edwige Danticat, formerly of Haiti, become household names in many parts of North America thanks to media promotions such as Oprah Winfrey's top ten book list or the purchase by Hollywood of movie rights for a novel. A broader audience, however, does not guarantee challenges to the socioeconomic structures that continue to repress precisely this writing and any other kind of production by women of color. On the more negative side of this popularity is a fetichizing identity politics that encourages both consumers and promoters of cultural products such as fiction to reduce writers to specific subject positions such as the "double bind" of being both "black" and "woman." In short, it may be assumed that writers who fit this bill represent certain voices and are not only qualified but "should" in fact speak to certain issues. This double bind is by no means to be overlooked, but it is experienced differently and need not be essentializing. Like the fiction of writers mentioned above, L'espérance-macadam seems like a novel that could earn a similarly 
motivated popularity, especially now that French Caribbean writing in general is gaining a readership in English. As a translator, I hope that in (re)writing the novel, I may better see how this discourse and related ones can be reshaped and determined differently.

My position as translator is certainly no less mediated than that of the author. Myriam Diaz-Diocaretz, translator of Adrienne Rich into Spanish, borrows from Foucault in proposing the "translator function" as a network that creates signification and is more important than the translator as an individual, man or woman, (cited in Robinson, 1997, p. 74). Elaborating on her definition, Douglas Robinson contends that this collective social construction imposed on any translator pushes her to conform her professional activity to hegemonic norms of text selection and the methods of translation deemed the most useful to society. All counter-hegemonic translation is then explained by the existence and influence of oppositional social groups who construct for their members oppositional author and translator functions (pp. 75-76). Ultimately, when ideological tensions in the work of translation are revealed, certain decisions too often considered to be technical extend to ideological circles and thus become problematic, leaving one faced with the choice of submitting to hegemonic power or undergirding an ideology that would not necessarily please the author and that might alienate part of the public (p. 77).

In our translation, we are still too caught up in the daily issue of which words to look up to face questions of alienating our hypothetical publics, and we have already opted to try to please the author. However, the question of ideological circles versus technical decisions is one of particular importance to our efforts and to those of anyone "translating" the French Caribbean. In general, these circles have either been drawn tightly to questions of technique - how to represent the spectrum of language - or drawn loosely to issues of recuperation - how the "métropole" appropriates this language as a "renewal" of French (DeSouza, 1995, p. 187). The latter circles could also be extended to encompass the practice of bringing French Caribbean discourses into English. For example, US publishers take advantage of a certain cultural capital already accorded things French by diffusing translations from French for the consumption of a largely elite (in the broadest sense) anglophone literati. For example, because France underscored the value of certain kinds of writing in the French Caribbean by awarding the Prix Goncourt to Patrick Chamoiseau in 1992, there has been a recent rash of translations of Chamoiseau's 
fiction into English.

Rather than dwell on the contested idea of recuperation, I will draw ideological circles based on the representation of language in $L$ 'esperance-macadam. The plurilingual aspects of the text - Creole, French, English, and the French Caribbean spectrum that integrates Creole and French - are indeed important in this novel. It has been suggested that "creolized French" à la Jacques Roumain (Haiti) or Patrick Chamoiseau (Martinique) offers a desirable option for translating a black American vernacular (Lavoie, 1997, p. 117), and certainly one might consider the inverse. Richard Philcox, translator of several novels by Guadeloupean writer Maryse Condé, admits that the temptation is there but that he distances himself from it since the language does not correspond with that of the island of Guadeloupe (Kadish, 1996, p. 752). An equally feasible option that Philcox rejects for the same reasons entails recourse to a Caribbean English and to a Creole that is based lexically on English (p. 752). In May 1999, Pineau's first adult novel, La grande drive des esprits, appeared in English thanks to the work of Michael Dash, a professor and critic already known for his translations of Edouard Glissant's Caribbean Discourse and The Ripening. Of anglophone Caribbean origin, Dash possesses the linguistic ability to render Pineau's language in a more regional English. Here, I disagree with Philcox's notion of how to represent Guadeloupean specificity. Dash's ability is important because it allows for certain claims, for example, the idea that Caribbean language of any kind breaks with the scope of received standard pronunciations and grammars and with the prescriptive attempts of US, Canadian, or British dictionary publishers; that a Caribbean readership might be constructed perhaps at the expense of a non-initiated and largely non-Caribbean public, thus shifting the audience for a translation; and above all, that a pan-Caribbean vision can stand behind this linguistic representation. Furthermore, this choice for translation may favor local knowledge by making possible the representation of fauna, flora, and even certain incarnations of good and evil that are repeated from one island to another, thereby rendering useless the esoterism of footnotes or a glossary and underscoring the words that already circulate in the target language to represent these phenomena.

Our group does not possess this linguistic dexterity and has a hard time imagining a readership outside North America, and I would guess, a readership that does not share other traits with us such as our educational values and our primarily white, middle-class, liberal 
desires. In a conversation I had with Dash several years ago, he was clear that his priorities would not allow him to translate $L$ 'espérancemacadam. Adopting the ideological choices involved in his translation of La grande drive des esprits would imply adding at least one "native" or "near-native speaker" of West Indian English to our group (and here we encounter the problematic of assumed and essentializing authenticity) or abandoning the project in hopes that someone with a "more appropriate" background might undertake it. Yet - and I am grateful to Dash for the generous spirit with which he received my ideas on the subject and his wish to promote Pineau in any manner - I will argue that another set of ideological circles can be drawn that challenge another set of hegemonic representations and afford different constructions of readership and visions of connection.

\section{Of Genders and Remainders}

These circles, about which I spoke to Dash, concern gender, which has become crucial to our group's reading of $L$ 'espérance-macadam and to our desire to see it published in a North American context. For the moment, I will explain these circles in terms of a "remainder." Translation theorist Lawrence Venuti, citing J. J. Lecercle, defines remainder as the minor variables of language that are subjected to a major form:

The linguistic variations released by the remainder do not merely exceed any communicative act, but frustrate any effort to formulate systematic rules. The remainder subjects the major form by revealing it to be socially and historically situated, by staging "the return within language of the contradictions and struggles that make up the social" and by containing as well "the anticipation of future ones". (1998, p. 10)

Venuti then borrows from Gilles Deleuze and Félix Guattari's notion of a minor literature - one that submits the major language to constant variation, thus alienating it - to take a stance in favor of minoritizing translations in which "sociolects striated with various dialects, registers, and styles" call into question the "seeming unity of standard English" and recognize the ethnocentricity of translation (p. 11). In sum, "Good translation is minoritizing: it releases the remainder by cultivating a heterogeneous discourse" so that the source text is not assimilated but rather signified as an autonomous existence "behind (yet by means of) the assimilative process of the translation" (p. 1). Much like Robinson's ideological circles, Venuti proposes that the 
remainder can be studied so as "to articulate and clarify - in terms that are at once textual and social - the ethical and political dilemmas that translators face when working in any situation" (p. 30). Venuti's objectives in minoritizing translation are to create a readable text whose remainder causes little enough disruption for a wide range of readers to be interpellated and for reading patterns to be altered (pp. 12-13). To illustrate, he cites his own translation of a novel by nineteenth-century Italian writer I. U. Tarchetti, whose Gothic style challenged the realism of Anglo-American fiction and the standard dialect of English and found favor among both "elite" and "popular" readers (p. 18).

Despite his efforts to include the social, Venuti's theory is problematic due to its reliance on the notion of a fixed text, that is, the problematic "text itself." While dictionaries, academic institutions, and other "authorities" certainly work to codify language, linguistic practices rarely conform to all codes, just as my language here no doubt ruffles sensibilities that may arise from the national border between Indiana where I write and Montreal where this article is published or from other ideas of what constitutes scholarly writing. In short, all discourses might be studied for that which is the remainder, and this remainder will shift according to the reader.

This point merits further elaboration for it touches on reasons for which a translation of L'espérance-macadam may meet with the kind of success that Venuti hopes to create through the practice of minoritizing translation. As Milan Kundera (1991), Derek Walcott (1997), and other critics reveal, fiction written in the French Caribbean in the last fifteen years elicits interest primarily for the way in which Creole operates on more codified French - the Creole "remainder." This interest is largely technical and aesthetic, with little concern for the ideological circles mentioned above. Admittedly, the challenge of translating this Creole-inflected French inspired my own critical inquiry into the French Antilles and Haiti when I was an undergraduate and compelled me to pursue language skills, literary analysis, and translation theories at new levels. Concerning ideological circles, this remainder can be deemed positive, in the sense of challenging hegemonic practices by "minoritizing," or more negative for the extent to which it is easily coopted and reified as exotic by hegemonic metropolitan institutions whose economic motivations align with those of the state in reducing and exploiting the islands in such a way that ultimately represses local production and economic and cultural development. 
If Dash's West Indian language suggests one kind of remainder and my own preoccupation with gender another, then no doubt other remainders might be considered, including what Venuti refers to as "dialect, register, or style" (p. 12). In L'espérancemacadam, allusions to Caribbean history (Christophe and Ésabelle "ruaient dans l'exaltation des premiers voyages [...] frais-ensorcelés par la découverte des terres neuves. " p. 31), to the Chicago Untouchables (p. 29), and to she-devils and other mythic figures constitute a range of cultural references specific to the French Antilles and also contribute to a "remainder". The proliferation of remainders undermines the very notion, for at some point, all language becomes a remainder of sorts. In speaking of a gendered remainder or Creole remainder, the codes that are opposed are not the same. Nevertheless, by applying a feminist perspective to the study of these two categories, I hope to uncover what Venuti attempts to theorize through his notion of the remainder: "[...] the return within language of the contradictions and struggles that make up the social" and "the anticipation of future ones" (p. 10).

\section{Gender Troubles}

It has been suggested that in Guadeloupe there exists a distinctly gendered relationship to language that takes part in what A. James Arnold calls "two sharply gendered cultural visions" (1994, p. 5). While I agree with this notion, I would argue with Arnold's substantiation that women writers refuse to write theory. In making this assertion, he overlooks Maryse Condé's work via literary criticism such as La civilisation du bossale (1978) and La parole des femmes (1993). More to the point, his narrow definition of "theory" implies that women writers do not necessarily reflect on their production because they lack a certain kind of metadiscourse. I would argue that the opposite actually obtains, and that both the fiction and interviews of Gisèle Pineau and Maryse Condé can be read to counter or rework some of the "theoretical" discourse of the Martinican trinity who authored Éloge de la créolité. Given the "the mobility of connotations" and "the practice of a programmatic writing by the male-dominated world," translation renders particularly salient "the ideological stand of an author struggling to transgress previously existent linguistic and cultural codes" (Diaz-Diocaretz, 1985, p. 150).

In L'espérance-macadam, I read an ideological stand in favor of women. The first paragraph sets the tone by alluding to five female characters or roles for women while only one possibly male name is 
given (p. 7). In the first two chapters alone, more than twenty femininegendered nouns identifying women appear, among which are l'innocente, la simplette, Santa Maria, donzelle, Négresse, bougresse, dévineresses, chabine, femelles, La Vorace, La Folle, la petite, femmeschiennes, femmes en chaleur, manm'zelle, servante au grand coeur, bonne d'enfants, madame offensée, and manawa sans culotte (sic). Women are also classified in list form in several instances. For example, Savane, the squatter neighborhood in which Éliette resides, is defined largely by its female inhabitants: "À Savane, y avait des manmans aveugles, muettes et sourdes. Bougresses bancroches un quart déboussolées, courant derrière la destinée pour réclamer un dû. Tristes créatures effarées. Femelles à cheveux ferrés. Chairs sapotille bâtardes en jactance perpétuelle. Madones à sac et souliers vernis les dimanches de Je crois en Dieu, et puis sacrées injurieuses les jours sans Jésus-Christ, sans foi ni loi"' (p. 15).

The challenge that such taxonomies pose for translation are multiple. One consideration relates to historical encoding and local linguistic practices. While without the capital letter, nègre in Creole can signify guy or man, as in the Martinican phrase $S a$ 'w fè, nèg? (What's up, man?), négresse is used less frequently and clearly implicates skin color. The fact that both terms are capitalized in the novel is, in my reading, a valorization of the color coding. Bougresse, not capitalized, is the feminine form of the Creole (and archaic French) loan word bougre, also signifying guy or man but free of color connotations and used liberally in speaking; the feminine form is rare, and I surmise that Pineau's use may constitute a conscious attempt to develop a specifically feminine lexicon. Manawa, a pejorative term for prostitute, is also borrowed from Creole, where it developed as a calque of the English "man-o'-war" - a reminder of the women who earned their living by soliciting seamen in Caribbean ports. Finally, chabine, which Richard Philcox translates as "yellow" (Kadish, 1996, p. 758) but which additionally connotes beauty and sexual proclivity, is just one of many terms based on skin color and phenotype that implies personality traits as well. Pineau uses these terms sparingly in this novel, and it might be fruitful to study how her practice differs from that of the male créolistes Chamoiseau and Raphaël Confiant of Martinique, especially where racialized designations for women are concerned. More important here, these calques and loan words from Creole often speak to the historic, social, and economic situations of women in the Caribbean. For this reason, our group maintains all of them except bougresse in our translation and italicizes them only the 
first time they appear. However, we cushion some as unobtrusively as possible to help the uninitiated reader. For example, several pages after the first appearance of chabine in reference to Ésabelle, we translate sa belle (p. 32) as "his blond beauty."

Other terms in the list suggest differences that are likely to be flattened in English. Femelles (used generally for animals in French), femmes-chiennes, and femmes en chaleur could all be translated as "bitches" with a qualifying adjective. Similarly, bougresse, servante au grand coeur, chabine, La Vorace, and La Folle are most obviously translated by some form of "woman" or "girl," - i.e., "woman," "bighearted servant (woman)", "yellow girl", "The Greedy (Woman or One)", and "The Madwoman" - thus either adding a word to preserve gender or losing the variation in terms. The proliferation and variation of these terms, some of which are less than flattering, again call attention to the socio-economic status of women and to differences among women as a group. We hesitate then to let context impute gender or to let terms repeat themselves. Equally important, through indirect discourse many of the less savory appellations are attributed to Éliette, who was twice married and speaks a "proper" French - signs of her middle-class aspirations and of the values by which she would like to rationalize her lack of involvement in the problems around her. Ultimately, among the many possibilities for translating these "types" of women, we aim to maintain both gender and French Caribbean specificity. Hence our translation of the passage cited in French two paragraphs above: "In Savane were blind, deaf, and dumb mothers. Bowlegged girls, half disoriented and running after destiny to claim their due. Sad and frightened creatures. Females with hair of steel wool. Bastard sapotilla bodies perpetually bragging. Madonnas with purses and polished shoes on the Sundays of 'I Believe in God,' then holy terrors on the days without Christ, without faith or law."

Joining the proliferation of signifiers for women is a range of representations of female sexuality. Éliette's sexuality expresses itself primarily in relation to her wish to become a mother: "Deux fois mariée...C'étaient de bons bougres. Avec eux j'aurais pu chanter La Vie en rose. Mais, par la faute de l'enfant qui venait pas..." (p. 11). In fact, Éliette claims that she didn't want men, hence her late marriage at the age of 35. Yet the thoughts attributed to her betray her when she wonders if her lack of children stems from having let her "chair rassir" and when she dreams of her first husband's return to "possess" her as he did on their wedding night (p. 19). The description of her second 
husband reveals the extent to which her desire turns around physical traits evincing fertility: "Ses gros bras, ses fesses pommées dans son pantalon, sa poitrine plus large que ma fenêtre ouverte et la puissance qu'il dégageait dans son souffle de bœuf, tous ces étalages en vitrine m'ont couillonnée...Je m'étais dit: 'Éliette, ma fille ! ce fer-là te baillera un enfant"' (p. $19 \mathrm{sic}$ ). The fact that Éliette lives with the irony of having been unable to bear a child while around her teem unwanted children and [m]anmans sans sentiments (p. 14) suggests a deconstruction of the notion of maternal instinct in the novel. Even mothers who want and love their children can experience a shift in feelings, as with Rosette, who earlier judged a woman for throwing her baby over the bridge but ends up confessing, "Aujourd'hui, je pourrais tuer ma propre chair à mon tour" (p. 60).

The desire of other women is largely circumscribed by their economic situations: "Jeunes Négresses à demi bourgeonnées qui avaient longtemps marché droit [...] Las, sitôt laissée l'école, elles devenaient femelles, savantes en vices. Robe relevées, assurées que bondas et tétés allaient les délivrer de la misère, leur donner les richesses de la terre, les sept merveilles du monde" (p. 14). Ésabelle, who for a time juggles two male lovers, finally chooses the one who has a regular job and can purchase the necklace she craves. Rosette seeks physical well being and freedom from responsibility, which she finds initially during baths with the other women at a rasta camp: "Rester sans remuer grand vent. Écouter. Simplement respirer... Jamais Rosette n'avait éprouvé un tel sentiment de plénitude [...] Et elle s'en revenait comblée, la chair agitée, empreinte du même bouleversement qui l'avait meurtrie et pénétrée la première fois qu'elle et Rosan avaient mêlé leurs corps" (p. 132).

The challenge in translating these representations of female sexuality involves the question of Creole loan words suggested by my title. With Luise von Flotow, I hold that women writers, including Pineau, "have looked for and developed vocabulary for censored and denigrated parts of the female anatomy" (1997, p. 17) and that the "work of reclaiming some of this derogatory vocabulary and developing new terms is also the work of the translator" (p. 19). Pineau's key strategy is to use Creole loan words and calques such as coucoune or bonda ("ass") in the French text. This practice is consistent with language practices in the French Caribbean, where Creole is used more often than French for sexual innuendo and puns. Creole likewise affords less taboo terms for body parts, as is attested by 
the metonymy Éliette - who would be deemed "Victorian" by English-speaking standards - applies to her second husband when she refers to him as "ce fer-là" in the passage cited two paragraphs above. $F e r$ is a calque of the Creole fe signifying phallus. Of course, Pineau's language should not be presumed to reflect the linguistic practices of the islands, just as her text, like that of any "third-world writer" should not be read as a documentary or realistic depiction of life (von Flotow, 1997 , p. 84). Yet her choice of language allows her to represent women's bodies and desires as more ordinary, less negative, and often less stuffy than what is possible within the seemingly puritanical codes of English.

Our strategy for translating Creole loan words and other physiological terms depends upon context, i.e., to which character, if any, the term is attributed; its place in the diachronic organization of the novel; and the discourse surrounding it. In the sentence, "Éblouis, tous, à Savane, voulurent cueillir ce fruit [...] même les vieilles à sang épais, tétés sans lait, coucounes amères, comme Éliette" (p. 45), my students and I opt for "breasts without milk" and "bitter coucounes" to make female body parts sound more prosaic and to maintain the Creole loan word in the interest of introducing the term. Twenty pages later, the description of Hortense's murder again assembles blood, breasts, and vagina, but in a different manner: "Sûrement qu'elle pensait pas qu'il aurait fini par la débiter et rassembler ses morceaux sur la terre battue de la cuisine et déposer ses deux tétés tremblants comme blancmanger sur une feuille de bananier, entre la tête aux yeux ouverts dans la stupéfaction, et la coucoune béante ensanglantée" (p. 65). In this graphic depiction, the use of the definite article - more common in French than in English - simultaneously creates distance and adds shock value. Hortense, toward whom readers are likely to feel sympathetic, is suddenly reified by this linguistic and physical dissection. Here, we translate coucoune as "vagina" (certainly not the pleasure-connoting "hoo-hoo") for a similar effect.

Calques and loan words from Creole such as coucoune, bonda, and tétés (this latter is both French and Creole) participate in a potentially erotic, humorous, more often banalizing discourse that might, when maintained in English, set up Pineau's language to be read largely as exotic and erotic, as if its key features related to bodies and sex. At the extreme, borrowing from it might even work to titillate something that $I$ do not get in the French version of the novel. To mitigate this potential, we as translators will evaluate our choices in the 
context of the entire translation and offset the potential reduction of the language by preserving direct discourse in Creole and by incorporating loan words and calques in other domains. Finally, with our awareness that representational practices can "distort the frame of reception itself" (Simon, 1996, p. 151) and that, to turn around my opening epigraph, we are translating into a language that does not yet exist, not Hortense but perhaps some other character will have a hoo-hoo.

\section{On the Phantom Limbs of a Translatrix, and Wherefore the French Caribbean}

To conclude, I will pull back from lexical considerations to address the messy business of why I took up translating L'espérance-macadam in the first place. When I first read this novel in 1995, I immediately began translating it. Why? Of course, I cannot see all the reasons. But to begin explaining, I will call on Douglas Robinson's metaphor of proprioception and the phantom limb. Proprioception is, in Robinson's words, "that sense that makes us feel our body as our own" (1997, p. 118). It allows an amputee to walk eventually on an artificial leg and creates the phenomenon of the "phantom limb" - the memory or sense of a body part that is no longer there, such as a foot that seems to itch when in fact that whole lower leg has been amputated. A translation, then, is the prosthetic device that replaces a textual limb "lost" through the target-language reader's inability to read a text in the original language and that can be made to feel "real" by the incorporation of the proprioceptive phantom:

[W] hat makes any text feel "at home" or "one's own" in any language is [...] the incorporation into it of a proprioceptive phantom, some nexus of felt experience that charges the text, any text, with the feel of reality, of "one's-ownness," of proprioception. A text that is charged with that felt experience [...] will feel real whether it is an original or a translation, whether it is domesticated or foreignized, whether it is easy or difficult to read. A text that is not charged with that felt experience will be like [...] a dead thing, a foreign object.

The advantage of thinking about appropriation along these lines is that it shifts our conceptual center of gravity from the intrinsic properties of texts to the reader's active construction of meaning. (pp. 119-120)

To extend Robinson's metaphor, I will claim using proprioception to construct meaning with regard to this novel: my felt experience charged the text in some way and brought it "home" to me. 
At that time, I had lived in the French Caribbean at two different periods and was preparing to return for several months. My desire to "identify" with the novel was honed both by the extent to which I was trying to make sense of my various subject positions in Guadeloupe and in Martinique - positions heavily inflected by my gender and my light skin color - and striving for an "understanding" of women friends there with whom I did not always connect as I would have liked. I was finishing a dissertation that focused largely on the male créolistes of Martinique and wanted a breath of fresh air away from this literary space with which I, as a woman, was not always comfortable. Translating answered several personal needs: pleasure, that is, "the playful, creative possibility of self-betrayal, of re-creating (in) language" (Levine, 1991, p. 182) which for me came about especially in juggling the Creole-French spectrum with English; my respect for the author; a sense of commitment to women's issues in general coupled with the awareness that my critical framework for identifying these issues often differed from that of my women friends in the Caribbean; a sense of gratitude toward these friends who put up with my blunders and welcomed me anyway; and finally, the problematic desire to "bring home" that which I couldn't have - the "real" limb or "original" text, whatever it was I didn't have and that set me apart as "foreign" wherever I went in the Caribbean. In other words, I wanted to appropriate (be this good or bad) in some way that difference that stood between my friends and myself, and translating this particular novel felt like a means to begin doing so.

My point in raising these questions of motivation is that a translator's baggage is never left at customs, and what that baggage contains may not always coincide with what the translator thinks is there. To cite Robinson again, "The question [...] is not whether you translate by recourse to a proprioceptive phantom; the question is whose phantom you're going to use, and how you're going to use it. The target-language text has to feel real, feel alive, for the translator to write it; but the proprioceptive reality and life imparted by hegemonic forces in society are quite different from those arising out of rebellious deviant idiosyncratic phantoms of the translator's counterhegemonic experience" (p.128). My own need to sift through issues of gender and race helps motivate my decision to translate this novel and to invite students to work with me. As Sherry Simon suggests, translation shows the borders which separate nations, cultures, languages or subjectivities to be blurred rather than reconfirm them: "It is the very economy of translation as a system regulating differences which has become 
problematic" (p. 165). With regard to both gender and language, the students and I have passed a point of no return in our sense of the permeability of borders even as we bump against differences just at the moment we begin to believe they no longer exist. In this sense, our work has served us primarily at the personal level where indeed, borders, are broken down and dialogue takes place: "[O]ne only grows into the translator's profession by learning to trust the intuitive process of finding and shaping interpretive phantoms within oneself - even if always in dialogue with others" (Robinson, 1997, p. 131).

Our group has not yet faced decisions concerning who publishes our translation - if publishers are interested at all - and how the novel will be framed apart from the translators' preface we have promised ourselves to write. We do know, however, that we are not looking to some of the large US presses that have contributed to the success of other authors who publish first in French. Yet we admit to not knowing if and how our translation might affect and determine linguistic change, much as we would like to join Venuti in believing it might.

Clearly, the extent to which our concerns about gender and location will be accorded weight by an editor is difficult to assess. What for us may "feel" like a counterhegemonic translation could end up feeding a current fad for things Caribbean and even woman-focused that does not take into account the complexities upon which we insist and that, as I mentioned earlier and have witnessed even at professional conferences, assumes in fiction a realistic depiction of French Caribbean life. As the French Caribbean works itself discursively into the geopolitical space of English-dominated Canada and the United States, these are some of the larger issues that we as a translation group continue to address. These issues merit a central role in debates concerning the consensus process implied in publishing translations and, I suggest, ongoing debates concerning the French Caribbean in general.

Earlham College

\section{References}

ARNOLD, A. James (1994). "The Erotics of Colonialism in Contemporary French West Indian Literary Culture". NWIG, vol. 68,

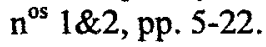


- (1995). "The Gendering of Créolité." Eds. Maryse Condé and Madeleine Cottenet-Hage.

BENÍTEZ-ROJO, Antonio (1992). The Repeating Island: The Caribbean and the Postmodern Perspective. Trans. James E. Maraniss. Durham, London, Duke UP.

BENNETT, Tony. (1983). "Texts, Readers, Reading Formations". The Bulletin of the Midwest Modern Language Association, vol. 16, $\mathrm{n}^{\circ} 1$, pp. 3-17.

BERNABÉ, Jean, CHAMOISEAU, Patrick, and CONFIANT Raphaël (1989). Éloge de la créolité. Paris, Gallimard/Presses Universitaires Créoles.

CHAMOISEAU, Patrick (1988). Interview. Notes bibliographiques caraibes, $\mathrm{n}^{\circ} 48$, pp. 9-22.

- (1994). Creole Folktales. Trans. Linda Coverdale. New York, New Press.

- (1997). School Days. Trans. Linda Coverdale. Lincoln, University of Nebraska Press.

- (1997). Solibo Magnificent. Trans. Rose-Myriam Réjouis and Val Vinokurov. New York, Pantheon Books.

- (1997). Texaco. Trans. Rose-Myriam Réjouis and Val Vinokurov. New York, Pantheon Books.

- (1999). Childhood. Trans. Carol Volk. Lincoln, University of Nebraska Press.

- (1999). Chronicle of the Seven Sorrows. Trans. Linda Coverdale, Lincoln, University of Nebraska Press.

- (1999). Seven Dreams of Elmira: a Tale of Martinique: Being the Confessions of an Old Worker at the Saint-Etienne Distillery. Trans. Mark Polizzotti. Cambridge, MA, Zoland Books.

CONDÉ, Maryse (1978). La Civilisation du bossale: réflexions sur la littérature orale de la Guadeloupe et de la Martinique. Paris, 
L'Harmattan.

- (1993). La Parole des femmes. Paris, L'Harmattan.

CONDÉ, Maryse et Madeleine COTTENET-HAGE, dir. (1995). Penser la créolité. Paris, Karthala, pp. 21-40.

DESOUZA, Pascale (1995). "Inscription du créole dans les textes francophones : de la citation à la créolisation." Eds. Maryse Condé and Madeleine Cottenet-Hage. Penser la créolité. Paris, Karthala, pp. 173190.

DIAZ-DIOCARETZ, Myriam (1985). Translating Poetic Discourse: Questions on Feminist Strategies in Adrienne Rich. Amsterdam, Philadelphia, John Benjamins.

ENSLER, Eve (1998). The Vagina Monologues. New York, Villard.

FOUCAULT, Michel (1979). “What Is an Author?” Ed. Josué Harari. Textual Strategies: Perspectives in Post-Structuralist Criticism. Ithaca, NY, Cornell University Press, pp. 141-60.

GLISSANT, Edouard (1981, trans. [1992]). Caribbean Discourse, Selected Essays. Trans. Michael Dash. Charlottesville, VA, University Press of Virginia.

- (1958, trans. [1985]). The Ripening. Trans. Michael Dash. London, Kingston, Jamaica, Heinemann.

KADISH, Doris Y. and MASSARDIER-KENNEY Françoise (1996). "Traduire Maryse Condé: entretien avec Richard Philcox". The French Review, vol. 69, $\mathrm{n}^{0} 5$, pp. 749-761.

KUNDERA, Milan (1991). "The Umbrella, the Night World, and the Lonely Moon." New York Review of Books, 19 Dec., pp. 46-50.

LAVOIE, Judith (1997). "Le français créolisé comme option de traduction du vernaculaire noir américain." Présence francophone, $\mathrm{n}^{\circ}$ 51, pp. 117-138.

LEGUIN, Ursula (1987). Always Coming Home. New York, Bantam Books. 
LEVINE, Suzanne Jill (1991). The Subversive Scribe: Translating Latin American Fiction. Saint Paul, MN, Graywolf Press.

PFAFF, Françoise (1993). Entretiens avec Maryse Condé. Paris, Karthala.

PINEAU, Gisèle (1993). La grande drive des esprits. Paris, Serpent à plumes.

- (1995). L'espérance-macadam. Paris, Stock.

- (1999). The Drifting of Spirits. Trans. Michael Dash. UK, Quartet Books.

ROBINSON, Douglas (1997). What Is Translation? Centrifugal Theories, Critical Interventions. Kent, OH, London, Kent State UP.

SIMON, Sherry (1996). Gender in Translation: Cultural Identity and the Politics of Transmission. London, New York, Routledge.

VENUTI, Lawrence (1998). The Scandals of Translation. London, New York, Routledge.

VON FLOTOW, Luise (1997). Translation and Gender: Translating in the 'Era of Feminism.' 'Manchester, UK, Jerome.

WALCOTT, Derek (1997). "Texaco." New York Review of Books, vol. $44, \mathrm{n}^{\circ} 13, \mathrm{pp} .45-48$.

ABSTRACT: Does Hortense Have a Hoo-Hoo? Gender, Consensus, and the Translation of Gisèle Pineau's L'espérancemacadam - This article uses an experiment in translating Guadeloupean writer Gisèle Pineau's novel L'espérance-macadam via consensus as a point of departure for analyzing the broader context of translating the French Caribbean for an English-speaking public. Previous efforts at translating recent French Caribbean fiction have focused on the challenge of representing the linguistic spectrum specific to the franco- and creolophone Caribbean. Here, it is suggested that Pineau's particular choices in inflecting French with Creole represent women in important ways, and that an awareness of this gendering of language is germane to translation into English. It is also 
acknowledged that desires on the part of English-speaking translators are not necessarily innocent but that an awareness of gender and local specificities can contribute to the consensus process entailed in publishing translations and should be part of ongoing debates concerning the French Caribbean in general.

RÉSUMÉ: Est-ce que Hortense a un «Hoo-Hoo »? Traduction au féminin de L'espérance-macadam de Gisèle Pineau - Dans cet article, une expérience de la traduction collective du roman $L$ 'espérance-macadam de Gisèle Pineau (Guadeloupe) sert de point de départ à l'étude de la traduction d'œuvres des Antilles françaises pour un public anglophone. Les efforts de traduction effectués jusqu'ici ont tendance à susciter un débat sur les difficultés de la représentation du continuum linguistique aux Antilles francophones et créolophones. Pour notre part, nous proposons ici que certains choix lexicaux de la part de l'écrivaine constituent une représentation importante de la femme antillaise et qu'une conscience du rôle du genre dans le langage est pertinente à toute traduction en anglais. D'ailleurs, si le désir de la part de ceux et celles qui traduisent n'est pas toujours innocent, cette conscience du genre et de la spécificité locale peut contribuer au processus de consensus qui fait partie de l'édition, et c'est ainsi qu'elle mérite un rôle au sein des débats concernant les Antilles françaises en général.

Key words: West Indian literature, women and translation, translation and pedagogy, literature-women's, Creoleness.

Mots-clés : littérature antillaise, traduction au féminin, traduction et pédagogie, écriture féminine, créolité.

Aletha D. Stahl: Department of Languages and Literatures, Earlham College, Richmond, IN 47374, USA

Courriel : stahlal@earlham.edu 